\title{
Novellisten Nexø
}

Ijuni 2013 udkom Martin Andersen Nexøs Samlede fortællinger i fire bind. Udgiveren, Henrik Yde, fortaller her om en mindre kendt side af Andersen Nexøs forfatterskab.

af editionsfilolog, dr.phil. Henrik Yde

A t Martin Andersen Nexø debuterede som novellist i 1898 med samlingen Skygger, fremgår af alle nyere danske litteraturhistorier. Men at han forblev trofast over for novellegenren, og at han helt frem til 1946 løbende udgav samlinger med nye fortællinger, er vistnok mindre kendt. Karakteristisk nok forbigår den hidtil nyeste oversigtsartikel om Nexøs forfatterskab - Johannes Nørregaard Frandsens i Dansk litteraturs historie fra 2009 - de senere samlinger og fortællinger i parentetisk tavshed.

Dertil kommer, at Nexø ved at forsyne flere af samlingerne med samme titel (fem forskellige bind med hovedtitlen Muldskud, tre forskellige bind med hovedtitlen De tomme Pladsers Passagerer) selv har bidraget til at skabe nogen forvirring vedrørende omfanget af og rækkefølgen i sit novellistiske forfatterskab.

Lad os derfor begynde med en oversigt over denne del af forfatterskabet. I Nexøs levetid udkom følgende bøger med nye fortællinger:

1898: Skygger

1900: Muldskud

1905: Muldskud. Anden Samling

1908: Af Dybets Lovsang

1911: Barndommens Kyst
1913: Lykken. En Fortalling fra Bornholms Nordland (separatudgave)

1915: Under Himmelen den Blaa

1918: Dybhavsfisk

1919: Undervejs

1921: De tomme Pladsers Passagerer (seks nye fortællinger og optryk af ni gamle)

1930: De sorte Fugle

1938: Mod Lyset. En Haandfuld Eventyr og Lignelser (fire nye fortællinger og optryk af tretten gamle)

1946: Et Skriftemaal (separatudgave).

I disse tretten bøger indgår i alt 85 fortællinger, skrevet over et halvt århundrede. At denne flid ikke var tilfældig, og at Nexø stod vagt ved sit novellistiske forfatterskab, fremgår af den iver, med hvilken han både herhjemme og i udlandet (navnlig i de tysktalende lande, hvor han havde sin største læserkreds) søgte at påvirke sine forlag til at optrykke fortællingerne i stadigt nye eller samlede udgaver.

Af sådanne optryk udkom i Nexøs levetid (eller lige efter) alene herhjemme følgende tolv bind, redigeret eller godkendt af ham selv:

1913: Bornholmer-Noveller 1919: Lotterisvensken (separatudgave) 
1922, 1924 og 1926: Muldskud, bind I, II og III (samlede fortællinger)

1944: Lonningsdag (separatudgave, bibliofiltryk)

1946: De tomme Pladsers Passagerer. Skitser og Noveller, bind I-II

1949: Lotterisvensken og andre Noveller (skolebogsudvalg)

1954: Lotterisvensken (separatudgave)

1954: Ungdom og andre Fortallinger

1955: Lykken og andre Fortallinger.

De tomme Pladsers Passagerer. Skitser og Noveller, bind I-II og de to samhørende Ungdom og andre Fortallinger og Lykken og andre Fortallinger indeholder (med en enkelt overlapning) tilsammen hele den del af det novellistiske forfatterskab, Nexø havde ladet publicere i bogform i sin levetid. På hans initiativ udkom de samlede fortællinger således på dansk to gange, nemlig hhv. 1922-26 og 1946/1954-55.

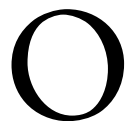

venfor er brugt begreberne 'noveller' og 'fortællinger'; Nexø selv brugte desuden betegnelserne "Æventyr", "Skitser", "Lignelser" m.fl. At sætte hele hans fiktionale kortprosa, som foruden de nævnte genrer også omfatter erindringer, rejseskildringer, anekdoter, skrøner, causerier, legender, allegorier og blandingsformer heraf, på ét begreb, er næppe muligt.

Det hidtil mest vellykkede forsøg på en typeinddeling af Nexøs novellistiske forfatterskab er gjort af litteraturhistorikeren Jørgen Aabenhus i et (upubliceret) universitetsspeciale fra 1977. Han påpegede her en udvikling fra de 'realistisk fiktive' fortællinger (bl.a. de tidlige bornholmernoveller) over de 'essayistiske' (f.eks. den selvbiografiske "Idioten" og den causerende "Vesterbro", hvor identite- ten mellem forfatter og oplevende fortæller er fremherskende) til de 'fantastiske', symbolske og allegoriske. Sidstnævnte genre udviklede Nexø under og efter 1. Verdenskrig med fortællinger som den dystre vision "De tomme Pladsers passagerer" og den symbolske antikrigsfortælling "Brodermorderen".

$\mathrm{M}$ an fornærmer næppe nogen ved at hævde, at hovedstolen $\mathrm{i}$ Nexøs novellistiske forfatterskab udgøres af det, Aabenhus kaldte de 'realistisk fiktive' fortællinger, som udgør omtrent en tredjedel af de samlede fortællinger. Her er Nexø på hjemmebane, hvad enten han skildrer hele livsforløb ("Hovsmeden fra Dyndeby", "Skæbne”), episodiske skæbneforløb ("Lotterisvensken", "Frænke") eller erindringsforløb ("Paradiset"). Fortællingerne drejer sig om enkeltpersoners skæbne, psykiske sammenbrud eller bevidste normoverskridelse.

De ovennævnte fortællinger udspiller sig alle i den førindustrielle bornholmske almue. De er med rette blevet fremhævet som værende blandt Nexøs ypperste, og de er ofte blevet jævnført med St. St. Blichers noveller og Johs. V. Jensens Himmerlandshistorier.

Blot vil kritikken gerne overse, at forfatteren få år senere udfoldede sig $\mathrm{i}$ samme genre med et lige så skarpt blik for storbyens moderne almue. "Murene", "Flyvende Sommer", "Frihedens Fe", "En Domfældelse" og "Trækfuglene" er blandt de både humoristiske og besk satiriske mesterfortællinger, der udspiller sig på bunden af samtidens København.

Andre kritikere har haft en udpræget tilbøjelighed til at læse forfatterskabet baglæns, til at projicere den ældre Nexøs politiske holdninger ned over hans ung- 


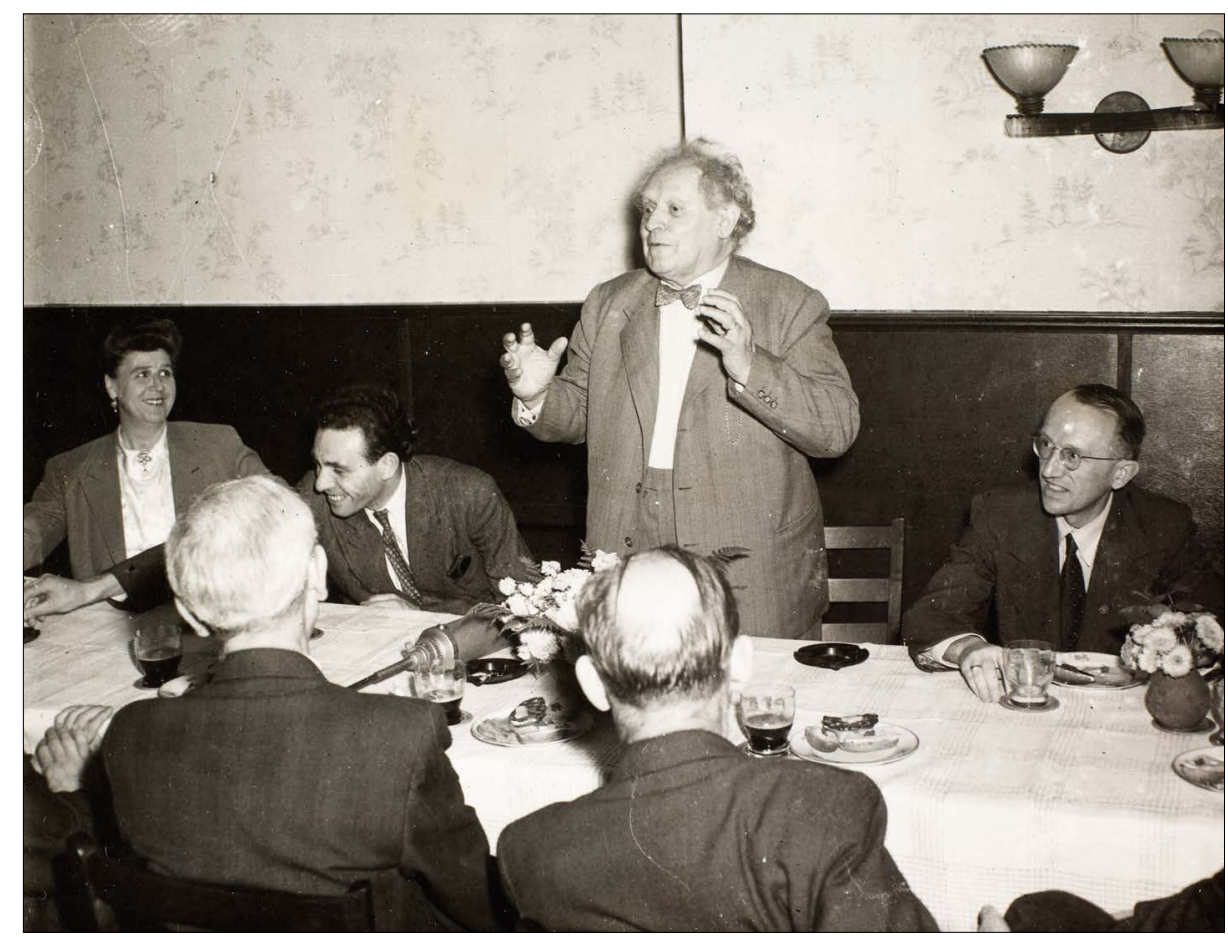

Nexø kunne fortalle historier, ikke kun i novelleform; her taler han ved en sammenkomst $i$ en kunstnerklub i Frankfurt am Main den 3. juli 1948. Yderst til venstre hans tredje kone, tyskfodte Johanna May (foto: Associated Press, Det Kongelige Bibliotek, Kort-og Billedsamlingen).

domsforfatterskab for dér at søge ansatser til det senere forfatterskab og forfatterens senere livsanskuelse. Derfor interesserede bl.a. Julius Bomholt og Børge Houmann sig mest for de ungdomsfortællinger, der skildrede rebellerende spansk almue (oftest "En Kvinderevolution") eller havde andet socialt motiv. Men de overså, at en fortællings grundholdning ikke afhænger af dens motiv, socialt eller ej, og at hele ungdomsforfatterskabet - herunder fortællingerne til og med 1905 - er præget af nihilistisk håbløshed.

$\mathrm{N}$

u er Nexøs Samlede fortellinger udkommet - for første gang $\mathrm{i}$ videnskabelig, tekstkritisk og kommenteret udgave: Tre digre bind brødtekst og et kommentarbind. Man kan håbe, at denne udgivelse vil bidrage sit til give et samlende overblik, og at den herved kan rette lidt op på de nævnte skævheder i læsemåder.

Man kan navnlig håbe, at udgivelsen vil bidrage til at genindsætte Nexøs bedste fortællinger i deres fulde ret som en kunstnerisk meget vægtig del af forfatterskabet. 